\title{
Determinants of property damage recovery time amongst households affected by an extreme flood event in Metro Manila, Philippines
}

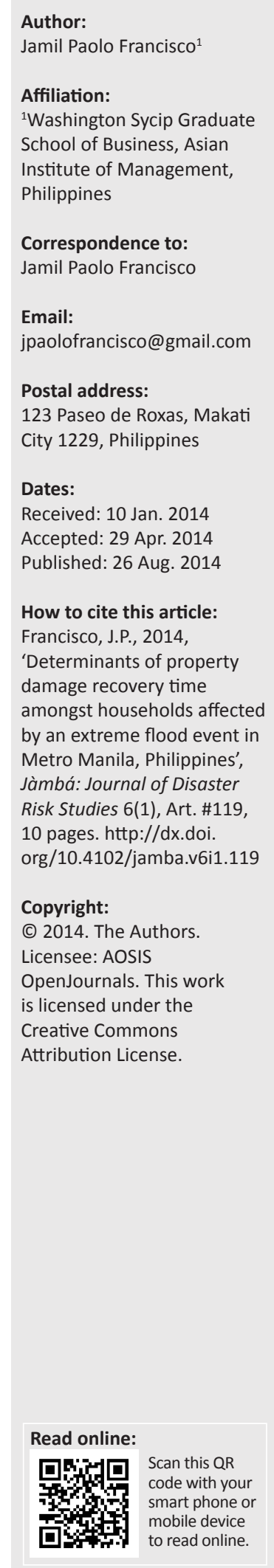

This study identified the factors that influence household recovery following an extreme flood event, measured in terms of the length of time to repair, rebuild or replace damaged private property. Data was obtained through a survey of 400 households in Marikina City in Metro Manila, Philippines. Results from the empirical analysis indicated that household income, access to credit (borrowing), the use of a flood alarm system, access to safe shelter, membership in a community organisation, adoption of disaster-specific anticipatory measures and adoption of general preventive measures significantly reduced the time it took for affected households to recover from property damage. Evacuation, relief aid, type of housing, education, household size and frequency of flooding in the area did not have significant effects.

\section{Introduction}

Many parts of Metro Manila, the national capital region of the Philippines, are particularly vulnerable to flooding. Its location between Manila Bay in the west and Laguna de Bay to the southeast makes it a drainage basin that is subject to frequent overflowing of storm waters. One of 17 cities and municipalities that make up Metro Manila, the City of Marikina experienced some of the worst flooding in recent history. In August 2012, following days of torrential rain, the Marikina River that runs through the city swelled to a height of $20.6 \mathrm{~m}$ - more than $4.5 \mathrm{~m}$ above its spill level - inundating a large portion of the city and damaging an estimated 15000 homes and buildings.

\section{Problem statement}

Extreme weather events can cause significant damage to private property. The increasing frequency of such events makes it important for households and communities to improve their adaptive capacity and to increase their resilience to the risk of damages. Governments and aid agencies seeking to help vulnerable communities must find effective and efficient ways to help those affected to recover more quickly from these events. There are many forms of help possible - from pre-disaster preparation and training, to disaster rescue operations and information dissemination, to post-disaster relief and rebuilding support. Given limited resources, local leaders must prioritise the most effective forms of aid that would have the biggest impact on vulnerable members of the community. Unfortunately, leaders often do not have enough information on what kinds of help matter most.

In response to this problem, we examined the factors that affect the speed at which households are able to recover - measured in terms of the time it takes to replace or repair damaged property. Using data obtained from a survey of 400 households in Marikina City, Philippines, we performed a linear regression of property damage recovery time on a host of factors, including socioeconomic data, types of pre-disaster measures taken by the household, dwelling structure characteristics and aid received. The speed at which households are able to recover is an indicator of disasterresilience, thus determining the factors that increase recovery speed will provide information on how best to help communities adapt and become more disaster-resilient.

\section{Background}

Located along the eastern border of Metro Manila, the City of Marikina is situated in a valley between the Sierra Madre Mountains to the east and the hills of Quezon City to the west. Most of the flooding in the city's low-lying areas is a result of the runoff from the slopes of the Sierra Madre mountain range that run along the east of Marikina Valley. Flowing through the mid-western portion of the city is the Marikina River, which drains the Marikina River basin (total drainage area of $582 \mathrm{~km}^{2}$ ) towards the Pasig River. The entire length of the Pasig-Marikina River is $27 \mathrm{~km}$. The Napindan Channel and the Mangahan Floodway connect it to the lake of Laguna de Bay in the southeast, which temporarily stores excess floodwater from the Pasig and Marikina Rivers. 
The Philippine Atmospheric, Geophysical, and Astronomical Services Administration (PAGASA) classifies three types of extreme weather events: extreme temperatures, dry days and extreme rainfall. Given no exact definition for an 'extreme flood event', such is interpreted by this study as flooding that results from extreme rainfall, which is defined by the PAGASA as rainfall exceeding $300 \mathrm{~mm}$ in $24 \mathrm{~h}$.

In early August 2012, intensified monsoon rains led to massive flooding in the national capital region and adjacent provinces - the result of $472 \mathrm{~mm}$ of rainfall in less than $24 \mathrm{~h}$. Floodwaters inundated $70 \%$ of the city's land area. According to the local government, a total of 4270 families were forced to evacuate. Although there were no human casualties, there was considerable damage to private property. No official figures have been released but local government estimates that around 15000 homes and buildings may have been damaged or destroyed.

\section{Literature review}

\section{Adaptive capacity and speed of recovery}

When hazards - defined by Twigg (2004) as potentially damaging events, which may cause loss of life or injury, property damage, social and economic disruption or environmental degradation - negatively impact individuals, households, firms or communities, they become classified as disasters. When such disasters strike, those affected must face the challenge of recovery and cope with the challenges of the changing environment. Adaptive capacity is the ability of a system to respond to these changes in the environment and to recover from damage that affects its ability to achieve its purpose (Dalziell \& McManus 2004). The speed and/or ease at which those affected by disaster can recover can thus be interpreted as a function of adaptive capacity.

The process of adaptation requires a capacity to learn from past experiences and to apply these lessons to cope with future events. When people know that an event may occur in the future because it has happened in the past, they come up with ways of coping with it (Blaikie et al. 1994). Numerous studies have tried to assess or measure adaptive capacity using several criteria, indices and variables typically selected by the researcher (Brooks, Adger \& Kelly 2005; O'Brien et al. 2004; Rayner \& Malone 2001; Van der Veen \& Logtmeijer 2005). One such criterion, developed by Smit and Pilifosova (2001), identified six determinants of adaptive capacity of communities in the context of climate change: (1) economic resources, (2) technology, (3) information, skills and management, (4) infrastructure, (5) institutions and networks and (6) equity.

A number of recent studies have used these determinants to assess the adaptive capacity of local government units, community organisations and households in East and South-East Asia (Jarungrattanapong \& Manasboonphempool 2011; Peñalba \& Elazegui 2011; Shen et al. 2011). Susandi et al. (2011) used recovery time to assess the adaptive capacity of households in Jakarta, Indonesia following a devastating flood in February 2007. They found household characteristics, knowledge and skills on what to do when disaster strikes, as well as total household loss to have a significant impact on recovery but did not find economic (income) and technological factors (willingness to evacuate, distance to city hall) to have a significant impact.

\section{Research method and design Conceptual and analytical framework}

To assess adaptive capacity, this study also examined property damage recovery time - measured by the length of time (in days) it takes for a household to fully replace or repair damaged private property. As recovery is the first step to adaptation, indicators of adaptive capacity were applied to the analysis of factors that influence such recovery. Following Smit and Pilifosova (2001), with minor revisions, several indicators were adopted as determinants of recovery time (see Table 1).

A liner regression model of the following specification was used to examine the effects of each variable:

$R=\alpha+b \beta h+\gamma c+\delta_{1} x_{1}+\delta_{2} x_{2}+\delta_{3} x_{3}+\delta_{4} x_{4}+\delta_{5} x_{5}+$

Where $R$ is property damage recovery time measured in the number of days to fully repair or replace property damaged

TABLE 1: Determinants of recovery.

\begin{tabular}{|c|c|c|}
\hline Determinant & Indicator variable & Rationale \\
\hline Economic resources & $\begin{array}{l}\text { - Real estate property ownership } \\
\text { - Vehicle ownership } \\
\text { - Household income } \\
\text { - Sources of income } \\
\text { - Access to credit }\end{array}$ & $\begin{array}{l}\text { Greater access to economic resources increases the speed of recovery. } \\
\text { Asset diversity reduces damage risk and increases likelihood of quick recovery. }\end{array}$ \\
\hline Infrastructure & $\begin{array}{l}\text { - Degree of permanence } \\
\text { - Housing characteristics (number of floors, primary } \\
\text { construction material used etc.) } \\
\text { - Access to electricity and water }\end{array}$ & Housing characteristics affect vulnerability, cost of damages and repairs, and speed of recovery. \\
\hline Information and skills & $\begin{array}{l}\text { - Training in disaster preparedness } \\
\text { - Indigenous knowledge } \\
\text { - Learning from previous disasters }\end{array}$ & $\begin{array}{l}\text { Access to information and disaster preparedness increase the likelihood of timely response } \\
\text { and smooth recovery. }\end{array}$ \\
\hline Technology & $\begin{array}{l}\text { - Access to communications network (TV, radio, } \\
\text { - telephone, Internet etc.) } \\
\text { - Access to evacuation centres } \\
\text { - Willingness to evacuate }\end{array}$ & Effective communications guarantee a quicker response to the disaster and quicker recovery. \\
\hline Social capital & $\begin{array}{l}\text { - Membership in community organisations } \\
\text { - Cooperation with other members } \\
\text { - Sources and types of assistance available to household }\end{array}$ & $\begin{array}{l}\text { Social, religious and community organisations reduce impact of damages from disasters and } \\
\text { facilitate access to support during and after the crisis. }\end{array}$ \\
\hline
\end{tabular}


during the flood. The coefficients $\beta, \gamma$ and $\delta_{\mathrm{n}}$ represent the effects of a unit increase in each of the explanatory variables represented by the vectors $h, c$ and $x_{1}$ to $x_{5}$ on property damage recovery. The vector $h$ represents household characteristics apart from income, such as number of household members residing in the current address, number of years of schooling of the household head and the frequency of flooding in the area. The vector $c$ includes dummy variables indicating the types of coping strategies adopted by the household. Each $x$ vector represents a host of indicator variables under each of the categories of determinants of adaptive capacity as listed in Table 1 . The vector $x_{1}$ represents access to and ownership of economic resources, $x_{2}$ represents housing characteristics (infrastructure), $x_{3}$ represents access to information and mastery of skills that facilitate adaptation and recovery such as disaster preparedness, $x_{4}$ represents access to communications technology and evacuation centres and $x_{5}$ represents affiliation with and support from social, religious and community organisations.

Following Schwarzer and Schwarzer (1996), four types of coping strategies were identified - reactive, anticipatory, preventive and proactive measures (Table 2). Reactive measures generally involve strategies that wait until the event is just about to happen or is already happening. The goal is to compensate losses or minimise harm as the crisis unfolds and as soon as it ends. For example, a usual reactive measure to flooding is to evacuate to higher ground or to move valuables and important documents to upper floors as soon as the flood hits or as floodwaters begin to rise in the vicinity of one's home. Clean-up and securing valuables as soon as the flood subsides are also another example of reactive coping behaviour.

Anticipatory measures involve making preparations just before the looming disaster strikes. It aims to deal with an imminent threat by addressing the problem through increased effort, getting help or investing resources. In the case of storms or flooding, anticipatory measures include buying or preparing emergency supplies, evacuating to safe shelter, or moving valuables to higher ground as soon as receiving storm or flood warnings and just before the flood hits or the storm intensifies.

Preventive coping behaviour involves building general resistance that reduces the overall risk of future disasters. As any kind of harm or loss could possibly materialise, the individual builds up general resistance resources, accumulating wealth, time, social bonds and skills, just in case'. The preparations tend to be general rather than specific to a particular crisis event and, as such, preparations tend to be undertaken a long time before a crisis strikes. Examples include attending disaster-preparedness seminars, preparing evacuation or disaster plans for the family and preparing emergency supplies or equipment long before any impending event.

Finally, proactive coping strategies, rather than being reactive to a specific threat or crisis, involve working towards a constructive path of action to create better life conditions and greater well-being. The goal is to improve conditions so as to offset, eliminate, reduce or modify crises so that if and when they do strike, the dangers they present are greatly diminished. By reducing vulnerabilities and improving circumstances, crises become less threatening and less disastrous.

\section{Site selection and survey methodology}

Marikina City is divided into 16 barangays and had a total population of 424150 residents (91 414 households) in 2010. All 16 barangays experienced varying degrees of flooding in August 2012, but the most severely affected were the barangays of Tumana, Nangka, Malanday and Jesus de la Peña, which are situated on the floodplain of the Marikina River. The study focused on a contiguous area formed by these four barangays (Tumana, Nangka, Malanday and Jesus de la Peña) that experience the highest flood heights as a result of their direct proximity to the river and are thus most severely affected during floods.

TABLE 2: Reactive, anticipatory, preventive and proactive measures.

\begin{tabular}{ll}
\hline Reactive behaviour & Anticipatory behaviour \\
\hline $\begin{array}{l}\text { Evacuate to safe shelter or higher } \\
\text { ground as soon as the flood reaches } \\
\text { home. }\end{array}$ & $\begin{array}{l}\text { Regularly check on weather updates } \\
\text { and flood warnings. }\end{array}$ \\
$\begin{array}{l}\text { Move belongings and documents to } \\
\text { higher ground as soon as flood hits. }\end{array}$ & $\begin{array}{l}\text { Move belongings and documents to } \\
\text { higher ground upon receiving } \\
\text { flood warning. }\end{array}$ \\
$\begin{array}{l}\text { Take along emergency equipment and } \\
\text { supplies upon evacuation as soon as } \\
\text { flood hits. }\end{array}$ & $\begin{array}{l}\text { Evacuate self and family to shelter } \\
\text { upon receiving flood warning. }\end{array}$ \\
$\begin{array}{l}\text { Help neighbours and/or relatives as } \\
\text { soon as flood reaches homes. }\end{array}$ & $\begin{array}{l}\text { Prepare emergency equipment and } \\
\text { supplies upon receiving flood warning. }\end{array}$ \\
$\begin{array}{l}\text { Contact neighbours and/or relatives to } \\
\text { warn about flood arrival. }\end{array}$ & $\begin{array}{l}\text { Construct sandbag dikes; reinforce } \\
\text { shelter upon receiving flood warning. }\end{array}$ \\
$\begin{array}{l}\text { Secure belongings and important } \\
\text { documents as soon as flood subsides. }\end{array}$ & $\begin{array}{l}\text { Help neighbours and/or relatives upon } \\
\text { receiving flood warning. }\end{array}$ \\
Start cleaning as soon as flood subsides. & $\begin{array}{l}\text { Contact neighbours and/or relatives to } \\
\text { spread warning. }\end{array}$ \\
$\begin{array}{l}\text { Repair shelter as soon as flood subsides. } \\
\text { Help neighbours and/or relatives as soon } \\
\text { as flood subsides. }\end{array}$ & $\begin{array}{l}\text { - } \\
\text { Contact neighbours and/or relatives } \\
\text { as soon as flood subsides. }\end{array}$ \\
\hline
\end{tabular}

\begin{tabular}{ll} 
Preventive behaviour & Proactive behaviour \\
$\begin{array}{l}\text { Buy and store food, medicines and } \\
\text { emergency supplies. }\end{array}$ & $\begin{array}{l}\text { Reinforce shelter or increase protection } \\
\text { from storms and floods. }\end{array}$ \\
$\begin{array}{l}\text { Temporarily move family to a } \\
\text { different location during typhoon } \\
\text { season. }\end{array}$ & $\begin{array}{l}\text { Build mezzanine, second or third floor or } \\
\text { roof deck. }\end{array}$ \\
$\begin{array}{l}\text { Attend disaster-preparedness } \\
\text { seminars. }\end{array}$ & $\begin{array}{l}\text { Migrate or plan to migrate to other areas } \\
\text { less prone to flooding. }\end{array}$ \\
$\begin{array}{l}\text { Help neighbours or community to } \\
\text { prepare for disasters. }\end{array}$ & Buy insurance against property damage. \\
$\begin{array}{l}\text { Cut or trim trees near house to } \\
\text { prevent damage during storms. }\end{array}$ & - \\
\hline $\begin{array}{l}\text { Prepare an evacuation plan for the family. } \\
\text { - }\end{array}$ & - \\
\hline- & - \\
\hline
\end{tabular}


A household survey was conducted for the purpose of gathering primary data on household experiences during and after the extreme flood event of August 2012. A total of 402 households were surveyed. Respondents were chosen using systematic random sampling. Using a city map, one starting point per enumerator was identified within the contiguous area formed by the four chosen barangays, from which surveyors counted-off to the tenth house from each starting point. If the tenth household refused to participate, the enumerator proceeded to the next house. After each successful interview, the enumerator had to count-off to the next tenth house from the participating household. Enumerators were specifically instructed to interview household heads or their spouses only, because they were expected to be most knowledgeable about damage costs, recovery periods and repairs undertaken following the flood. If the household head or his or her spouse was not available for interview, the enumerator was instructed to ask if and when he could return to interview the head of the household or his or her spouse, or to move to the next household if they declined to participate.

\section{Results \\ Household characteristics}

Respondents were asked to rate on a scale of 1-10 how well they thought they remembered the details of what had happened during the flood of August 2012. Out of the 400 households sampled, only the responses of those who gave themselves a rating of 7 and above were included in the analysis. A total of 379 samples were included in the final tally.

The typical respondent was a 44-year-old woman, who had completed 11 years of education, was married and had two young children (below age 12). They owned the two-storey house they lived in, which had electricity and a private water connection. There were two income-earning household members who generated a combined income of about PHP 20025 (USD 465) per month. Table 3 presents a summary of household characteristics.

\section{Economic indicators}

Most (71.5\%) of the households interviewed owned their homes but only $63.0 \%$ owned their land. This suggests that about $9.0 \%$ of respondents were de facto or informal settlers who did not have legal titles to their land. The average rental value of homes according to the estimates of respondents was PHP 3250 per month (USD 76 per month).

On average, each household had two income-earning members, generating a combined monthly income of PHP 20025 (USD 465). Of households interviewed, 20\% had at least one family member working abroad. About $24 \%$ of households owned a motorised vehicle (motorcycle or car). Amongst the most common household assets were appliances and electronics such as TV sets (95\%), mobile phones (91\%), radios $(77 \%)$ and washing machines $(60 \%)$.

Access to credit was inferred from responses on sources of funds used to finance repair or replacement of damaged property. Most (71\%) households depended on themselves, partly or wholly, to finance their recovery. About $20 \%$ borrowed from friends or relatives. Only 3\% borrowed from banks or used credit cards, whilst about $2 \%$ borrowed from social security. Quite notably, more than $12 \%$ of households borrowed from informal lenders that typically charged very high interest for short-term loans without collateral. The lack of access to affordable credit may adversely affect the speed and capacity of households to recover from a disaster.

\section{Infrastructure}

The homes of those who were interviewed ranged from small, rudimentary single-storey structures to expansive, three-storey buildings. The average number of floors was 1.64. About $56 \%$ of homes had walls made of cement, whilst $28 \%$ had walls made of plywood. In addition, $54 \%$ had floors made of polished cement, $17 \%$ were vinyl, $17 \%$ were made of marble, granite or ceramic, whilst $11 \%$ were either earthen or made of rudimentary wood shingles. Most households had roofs made of either corrugated tin $(84 \%)$ or coloured metal sheets (8\%). All households had electricity and 90\% had piped water connections.

TABLE 3: Respondent and household characteristics.

\begin{tabular}{|c|c|c|c|}
\hline Variable & Description & Mean & Standard deviation \\
\hline Age & - & 44.2 & 12.1 \\
\hline Gender & $=1$ if male, 0 if female & 0.3 & 0.4 \\
\hline Civil status & $=0$ if single, widowed or separated, 1 if married & 0.7 & 0.4 \\
\hline Education & Number of years of schooling & 10.5 & 2.7 \\
\hline Household size & Number of household members & 5.8 & 2.6 \\
\hline Young children & Number of children $\leq 12$ years & 1.6 & 1.4 \\
\hline Home ownership & $=0$ if owned, 1 if rented & 0.7 & 0.4 \\
\hline Number of floors & Number of floors of dwelling & 1.6 & 0.5 \\
\hline Water connection & $=0$ if connected to piped system, 1 if not connected & 0.9 & 0.3 \\
\hline Electric bill & Monthly electricity bill in PHP & 1334 & 1347 \\
\hline Overseas Filipino worker & $=1$ if a member of the household is working abroad, 0 if not & 0.2 & 0.4 \\
\hline Affiliation & $=1$ if affiliated with local community or religious or parish organisation, 0 if not & 0.2 & 0.5 \\
\hline Income earners & Number of income earners & 0.2 & 0.9 \\
\hline Income & Average monthly household income in PHP & 20025 & 19243 \\
\hline
\end{tabular}




\section{Information and skills}

Of respondents interviewed, $61 \%$ had only 10 years of education or less. Only $21 \%$ of respondents had previously attended training seminars on preparing for and coping with disasters. Most respondents received their training from the government $(46 \%)$ or non-governmental organisations (NGOs) (37\%). The majority of households (78\%) used past experience as a guide in dealing with the crisis. Almost all respondents $(97 \%)$ experienced the onslaught of Tropical Storm Ketsana (Ondoy) in 2009. Other sources of information on how to prepare for and cope with disasters included the media (41\%) and relatives or friends (7\%). When asked how prepared they thought they were for this flood, $49 \%$ said they were very well prepared, $34 \%$ said they were adequately prepared, $15 \%$ said they were not very prepared and $2 \%$ said they were not prepared at all.

\section{Technology}

Of households interviewed, 91\% had at least one mobile phone at the time of the flood; $95 \%$ had television, $77 \%$ had radio and $26 \%$ had a computer. The Marikina City government installed a flood warning system in 2011 that employed loud sirens that can each be heard within a $1.5 \mathrm{~km}$ radius. All respondents reported having received warning before the floodwater reached their homes; $41 \%$ heard and understood the sirens of the flood warning system, whilst $10 \%$ first learned about the threat of flooding through radio or television. Most households, however, received warning through word of mouth, either from barangay officials or local government or from neighbours and concerned relatives. On average, households had $3 \mathrm{~h}$ between the time of receiving the warning and the time that the flood reached their homes.

Upon receiving warning, the majority (58\%) of households started to move valuables and important documents to higher ground. However, only $36 \%$ of households started to evacuate themselves or some household members; $25 \%$ waited for further warnings. As soon as the flood reached their homes, only then did the majority of households (58\%) evacuate. About $38 \%$ of households also waited until the flood reached their homes before moving belongings and important documents to higher ground.

About $80 \%$ of households interviewed had access to safe shelter at the time of the flood but only $70 \%$ evacuated. Of those who decided not to evacuate, $51 \%$ said they felt that there was no need to move because their homes were safe. Less than 3\% said there was no accessible shelter. Almost half (49\%) of respondents said that they did not want to leave their valuables behind.

\section{Social capital}

The majority (79\%) of respondents were not members of any community or religious organisation. However, responses did seem to suggest that there had been some form of interaction and mutual support amongst neighbours, at least before the actual flood event. Of respondents interviewed, $44 \%$ claimed to have helped neighbours or the community to prepare for disasters in general, although the amount and kind of help given was not verified in the research. Only about $3 \%$ of respondents said that they had helped neighbours and/or relatives upon receiving flood warnings and less than $4 \%$ said they had helped out once the flood reached their homes. However, $13 \%$ of respondents said they had contacted neighbours and/or relatives upon receiving the flood warnings and $15 \%$ said they had contacted neighbours and/or relatives when the flood came.

Almost all (96\%) respondents said that they had received help during or soon after the flood, mostly from the government $(62 \%)$, or from neighbours, friends or relatives $(24 \%)$. The help they received was mostly in the form of food, water and clothing (77\%), medicines (32\%) and information (26\%) (see Table 4).

\section{Impact of the flood on households}

About $50 \%$ of respondents claimed that it flooded in their area more than once a year. The average flood height reported for the August 2012 flood event was $4 \mathrm{~m}$ outdoors and $3 \mathrm{~m}$ indoors. The intensified monsoon and resulting flood caused damage to property, including the dwelling structure itself and its contents - appliances, electronic devices and personal belongings. Most houses only needed thorough cleaning but others had damaged roofs (33\%), walls (29\%) and floors (22\%). The most commonly damaged household appliances were television sets $(48 \%)$, rice cookers $(47 \%)$, refrigerators $(44 \%)$, washing machines $(43 \%)$ and radios $(33 \%)$. Some households also experienced damage to their vehicles - cars (37\%) and motorcycles (32\%) (see Table 5 and Table 6).

The average amount of losses reported by households was PHP 33142 (USD 771), which was 165.0\% of the average

TABLE 4: Help received from others.

\begin{tabular}{llc}
\hline Question & Answer & Percentage \\
\hline $\begin{array}{l}\text { Did you receive any help from } \\
\text { others during or soon after? }\end{array}$ & Yes & 95.8 \\
& From government? & 62.3 \\
& $\begin{array}{l}\text { From neighbours, friends } \\
\text { or relatives? }\end{array}$ & 23.7 \\
& $\begin{array}{l}\text { From NGOs or community } \\
\text { or religious organisations? }\end{array}$ & 14.5 \\
What kind of help did you & Information & 25.7 \\
receive? & Shelter & 10.6 \\
& Food, water, clothing & 77.1 \\
& Medicine & 32.3 \\
& Financial support & 10.8 \\
\hline
\end{tabular}

NGOs, non-governmental organisation.

TABLE 5: Damage to dwellings.

\begin{tabular}{llllc}
\hline $\begin{array}{l}\text { Parts of } \\
\text { house }\end{array}$ & $\begin{array}{l}\text { Percentage of } \\
\text { households that } \\
\text { suffered damage } \\
\text { or loss }\end{array}$ & $\begin{array}{l}\text { Percentage of } \\
\text { households } \\
\text { that have replaced } \\
\text { or repaired } \\
\text { parts in the last } \\
6 \text { months }\end{array}$ & \multicolumn{2}{c}{$\begin{array}{l}\text { Average cost of repair or } \\
\text { replacement }\end{array}$} \\
\cline { 3 - 5 } & 21.64 & 56.10 & PHP & USD \\
\hline Floor & 33.25 & 66.70 & 3051 & 71 \\
Roof & 28.76 & 63.30 & 3595 & 84 \\
Walls & & & 6412 & 149 \\
\hline
\end{tabular}


monthly income of sampled households, or $13.8 \%$ of their average annual household income.

Six months after the flood event, more than half of households had repaired or replaced damage to their roofs $(67 \%)$, walls (63\%) and floors (56\%), which, on average, cost, PHP 3595 (USD 84), PHP 6412 (USD 149) and PHP 3051 (USD 71), respectively. Amongst household assets, damages to vehicles and computers were the most costly. However, $76 \%$ of households whose cars were damaged, $71 \%$ of those whose motorcycles were damaged and $42 \%$ of those whose computers were damaged had already replaced or repaired them within 6 months of the disaster. The high values may reflect the fact that households that owned vehicles and computers tended to have high incomes, which enabled them to repair or replace these high-priced assets relatively quickly (see Table 5 and Table 6).

Most households (71\%) financed the cost of repairs or replacement wholly or partially with their family savings. About $20 \%$ of respondents borrowed money from friends or relatives, whilst $12 \%$ borrowed from informal lenders. Only $5 \%$ of households availed credit through formal channels - banks, credit cards, or social security (Social Security System [SSS], Government Service Insurance System [GSIS] or Home Development Mutual Fund [Pag-IBIG]). Finally, $11 \%$ of respondents received monetary gifts or donations (see Table 7).

\section{Property damage recovery}

About $62 \%$ of households had not yet fully repaired or replaced all damaged property at the time of the survey (approximately 7 months after the flood event). Almost 21\% of those interviewed explicitly said that they could not afford the costs of repair or replacement of some or all damaged property (see Figure 1).

\section{Model results}

Results from the pilot test showed that respondents had difficulty remembering the exact time it took for them to repair or replace all damaged property. Answers were often given as a range of 1-2 months. To accommodate this, questions on how long it took for the household to repair or replace damaged property were modified to give respondents the following options to choose from, (1) less than 1 month, (2) within 1-2 months, (3) within 3-4 months, (4) within 5-6 months, (5) not yet repaired or replaced or (6) cannot afford to repair or replace. This question was asked for each item of property reported as having been damaged during the flood.

Responses of each household to the questions on property damage recovery time for all damaged items were then pooled together and the maximum reported repair or replacement time for all damaged items was used to represent the overall property damage recovery time of each household. As the responses obtained were in the form of 2-month time intervals, interval regression was used in place of simple linear regression in the empirical analysis. Interval linear regression is used to model outcomes that have interval censoring; that is, when the ordered category into which each observation falls is known but not that exact value of the observation.

TABLE 7: Financing repairs or replacements.

\begin{tabular}{ll}
\hline Question: How did you finance these repairs or replacements? & Percentage \\
\hline Own money or savings & 71.0 \\
Borrowed money from friends or relatives & 20.1 \\
Borrowed money from bank or credit card & 3.2 \\
Borrowed money from government or social security (SSS or GSIS) & 2.1 \\
Borrowed money from informal lenders & 12.1 \\
Gifts or donations from friends or relatives & 9.0 \\
Gifts or donations from government & 2.1 \\
\hline
\end{tabular}

SSS, Social Security System; GSIS, Government Service Insurance System.

TABLE 6: Damage to assets.

\begin{tabular}{|c|c|c|c|c|}
\hline \multirow[t]{2}{*}{ Assets owned } & \multirow{2}{*}{$\begin{array}{l}\text { Percentage of households that suffered } \\
\text { damage or loss }\end{array}$} & \multirow{2}{*}{$\begin{array}{l}\text { Percentage of households that have } \\
\text { replaced or repaired items in the last } \\
6 \text { months }\end{array}$} & \multicolumn{2}{|c|}{ Average cost of repair or replacement } \\
\hline & & & PHP & USD \\
\hline Radio & 32.76 & 63.54 & 1493 & 35 \\
\hline Television & 48.04 & 69.77 & 6337 & 147 \\
\hline Mobile phone & 10.20 & 77.14 & 3487 & 82 \\
\hline Computer & 19.19 & 42.11 & 13290 & 309 \\
\hline Camera & 13.33 & 30.00 & 4550 & 106 \\
\hline Bicycle & 21.90 & 60.87 & 1367 & 32 \\
\hline Motorcycle & 31.91 & 71.00 & 16282 & 379 \\
\hline Car & 36.96 & 76.47 & 265557 & 6175 \\
\hline Refrigerator & 44.49 & 71.29 & 6443 & 150 \\
\hline Microwave oven & 21.43 & 66.67 & 4292 & 100 \\
\hline Electric fan & 21.12 & 88.71 & 896 & 21 \\
\hline Washing machine & 43.42 & 71.72 & 4005 & 93 \\
\hline Rice cooker & 46.67 & 38.10 & 993 & 24 \\
\hline Table & 18.13 & 76.56 & 2816 & 65 \\
\hline Chair or sofa & 25.21 & 69.23 & 3366 & 78 \\
\hline Bed or mattress & 20.31 & 68.18 & 2678 & 62 \\
\hline Jewellery or artwork & 5.41 & 0.00 & - & - \\
\hline
\end{tabular}


With property damage recovery time as the dependent variable, explanatory variables used included several variables representing the five determinants of economic recovery - economic resources, infrastructure, information and skills, technology, and social capital - and variables representing the adoption of anticipatory, preventive, or proactive measures, total cost of property damage household characteristics, such as household size, level of education of household head and flood frequency. Table 8 provides a description of the explanatory variables used in the model.

The initial run included all indicators listed in Table 1 for each determinant of recovery (based on Smit \& Pilifosova 2001). However, some indicator variables, such as mobile phone and radio or TV ownership, access to electricity and piped water and learning from past experiences, did not vary much across the sample and thus had to be dropped. Other variables that were not found to be significant were also dropped to improve the results. Nonetheless, at least one indicator variable per determinant of recovery was preserved for the final regression model. Results of the interval regression model are shown in Table 9.

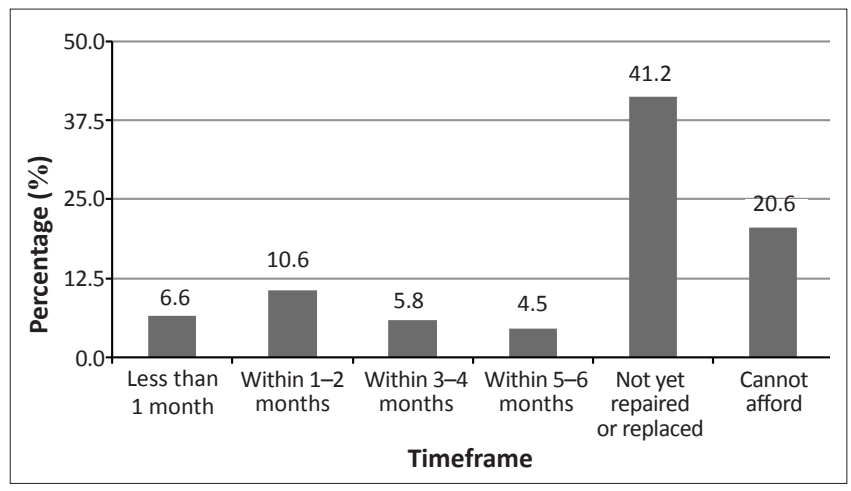

Source: Author's own creation

FIGURE 1: Timeframe in which respondents repaired or replaced damaged property.

\section{Discussion}

As expected, the total cost of property damage was found to be a highly significant determinant. Greater property damage cost, even when controlling for income, resulted in a longer recovery time. Average monthly household income was also highly significant. A larger income led to a shorter recovery. As expected, greater economic resources enabled richer households to recover faster. Access to credit as indicated by having borrowed money to finance repairs or replacements from banks, relatives, friends, or informal lenders was also a very significant factor that led to quicker recovery amongst households.

In terms of infrastructure, the degree of permanence, as indicated by whether the household possessed the property rights to their home (by lease or ownership) as opposed to being informal settlers or squatters, was found to be a significant determinant of recovery. Being an informal settler or squatter increased the length of full recovery. As this finding is observed even after having controlled for income, it can be inferred that informal settlers may have deliberately chosen not to repair or replace damaged property immediately. The finding that receiving aid from government and charitable institutions was not a significant determinant may also support this interpretation. Informal settlers were specifically targeted by local government relief efforts after the flood and yet the recovery period still tended to be longer for informal settlers. Repair or replacement of damaged property may not have been their priority.

Other infrastructure variables, such as the type of housing material and number of floors, were not found to have a significant impact. In contrast, information variables were found to be significant. Hearing flood alarm warnings reduced recovery time for households, perhaps as this would have allowed them to take anticipatory measures (such as moving belongings to higher ground or evacuating

TABLE 8: Description of variables for interval regression model.

\begin{tabular}{|c|c|c|c|}
\hline Variable & Mean & Standard deviation & Description \\
\hline Cost of property damage & 33011.16 & 118186.40 & Continuous \\
\hline Anticipatory measures & 1.00 & 0.05 & Dummy, 1 if taken, 0 otherwise \\
\hline Preventive measures & 0.99 & 0.07 & Dummy, 1 if taken, 0 otherwise \\
\hline Proactive measures & 0.44 & 0.50 & Dummy, 1 if taken, 0 otherwise \\
\hline Household income & 20025.07 & 19243.77 & Continuous \\
\hline Borrowing & 0.19 & 0.39 & Dummy, 1 if household borrowed from bank, credit card, relatives, or friends, 0 otherwise \\
\hline Informal settler & 0.18 & 0.39 & Dummy, 1 if yes, 0 otherwise \\
\hline Number of floors & 1.64 & 0.55 & Continuous \\
\hline Housing material & 2.56 & 0.31 & Ordinal, 1 = natural, 2 = rudimentary, $3=$ finished \\
\hline Heard flood alarm & 0.42 & 0.49 & Flood alarm; dummy, 1 if alarm was heard, 0 otherwise \\
\hline Attended disaster training & 0.21 & 0.41 & Dummy, 1 if attended, 0 otherwise \\
\hline Access to safe shelter & 0.86 & 0.43 & Dummy, 1 if yes, 0 otherwise \\
\hline Evacuated during flood & 0.77 & 0.49 & Dummy, 1 if evacuated, 0 otherwise \\
\hline Community organisation & 0.41 & 0.72 & Dummy, 1 if affiliated, 0 otherwise \\
\hline Years of education & 10.56 & 2.73 & Continuous \\
\hline Household size & 5.80 & 2.60 & Continuous \\
\hline Frequency of floods & 3.97 & 1.32 & $\begin{array}{l}\text { Ordinal, } 1=\text { less than once in } 5 \text { years, } 2=\text { once in } 5 \text { years, } 3=\text { more than once in } 5 \text { years, } 4=\text { once } \\
\text { a year, } 5=\text { more than once a year }\end{array}$ \\
\hline
\end{tabular}


TABLE 9: Results of interval regression model.

\begin{tabular}{lll}
\hline Explanatory variables & Coefficients & $p$-Values \\
\hline Cost of property damage & $1 \mathrm{E}-05^{* * *}$ & 0.002 \\
Anticipatory measures & $-21.092^{* * *}$ & 0.000 \\
Preventive measures & $-21.899^{* * *}$ & 0.000 \\
\hline Proactive measures & -0.252 & 0.715 \\
Household income & $-2 \mathrm{E}-04^{* * *}$ & 0.000 \\
\hline Borrowing & $-2.054 * * *$ & 0.006 \\
Informal settler & $2.353^{* * *}$ & 0.005 \\
Number of floors & -0.342 & 0.550 \\
\hline Housing material & 0.051 & 0.968 \\
\hline Heard flood alarm & $-1.441 * *$ & 0.037 \\
Attended disaster training & $1.579 *$ & 0.061 \\
Access to safe shelter & $-1.768 *$ & 0.078 \\
Evacuated during flood & -0.863 & 0.340 \\
Community organisation member & $-1.129 * *$ & 0.025 \\
Relief aid & -0.728 & 0.350 \\
Years of education & 0.089 & 0.470 \\
\hline Household size & 0.125 & 0.304 \\
\hline Frequency of floods & 0.333 & 0.161 \\
Constant term & $51.394^{* * *}$ & 0.000 \\
\hline
\end{tabular}

***, Significant at $99 \%$ confidence level; **, Significant at $95 \%$ confidence level; *, Significant at $90 \%$ confidence level.

family members) before the flood reached their homes. However, contrary to expectations, attendance in disasterpreparedness training appeared to have significantly increased property damage recovery time. There is not enough information available from the survey to explain this result. However, one may speculate that these disasterpreparedness seminars have not really prepared attendees to prevent property damage, perhaps focusing instead on understanding flood or weather warnings, developing evacuation plans and cooperating with the local authorities during disasters, with the ultimate goal being preservation of life rather than property damage mitigation.

In the case of technological determinants, having access to nearby safe shelter was found to have significantly decreased recovery time. Access to shelter would have allowed affected households to move their belongings and evacuate themselves to higher ground. However, evacuation per se was not found to be significant. Understandably, property damage may not have been significantly reduced by the evacuation of families to safe shelter because much of their property may have had to be left in their homes when they evacuated.

Damage to vehicles, for example, was the single largest contributor to total property damage costs. Many vehicle owners who did not incur flood damage to their vehicles reported having parked their cars in known flood-free areas, including homes of friends and relatives elsewhere. Most of those who experienced damage to their vehicles were either unable to move them to higher ground because the flood had already surrounded their area or were on the road when the flood hit the area.

Receiving relief aid from government, NGOs, friends or relatives and community organisations was not found to have had a significant impact on recovery. Relief aid was specified as provision of shelter, food, water, clothing, or monetary donations. Although these forms of aid provided temporary relief to affected households, they did not affect the time it took for households to recover from property damage. This does not undermine the importance of relief aid in the immediate aftermath of disaster. However, the findings suggest that governments and charitable organisations interested in helping families recover from property damage may find alternative strategies, such as extending affordable credit to affected households, to be more helpful than simply focusing on relief operations.

Membership in community organisations (whether civic or religious) was found to have significantly reduced recovery time amongst the sampled households. Not enough information was gathered in the survey to determine the mechanism by which social capital, in the form of community organisation membership, reduced recovery time. However, it is possible that membership in such organisations had provided support not necessarily in the form of relief aid. Moral or emotional support, sharing of technical know-how, or access to a broader social support network may have been instrumental in helping households with family members affiliated to community organisations to recover faster.

As for household characteristics, the number of years of formal schooling received by the household head did not have significant impact on recovery. Household size was also not found to be significant. Finally, frequency of flooding in the area of the household also did not have a significant effect on recovery from this particular disaster. This result is unexpected because flood frequency could be hypothesised to have either a positive effect on recovery speed as households adapt to frequent flooding in the area, or a negative effect as households too frequently affected by floods may find it difficult to recover between floods.

The types of coping behaviour adopted by households both in preparation for the monsoon season and during the actual disaster were expected to be major determinants of recovery as well. As all households that participated in the survey adopted reactive measures, the dummy variable for it was dropped. The dummy variables that were retained represented the adoption of anticipatory, preventive, and proactive measures. Results show that the adoption of anticipatory measures in preparation for this particular weather and flood event reduced property damage recovery time. Anticipatory behaviour includes activities such as monitoring flood and weather updates, moving belongings to higher ground upon receiving warning, preparing emergency equipment upon receiving warning and evacuating to safe shelter, all of which significantly reduced recovery time. The adoption of general preventive measures was also found to have significantly reduced recovery time. These measures, taken a considerable time before disaster strikes, include buying or storing food and medicine, temporarily moving family members to floodfree areas during the monsoon season, attending disasterpreparedness training, trimming trees near their property and preparing evacuation plans for the family. 
Contrary to expectations, the adoption of proactive measures, such as reinforcing homes, building mezzanines or second or third floors and buying property insurance against flood damage, did not have a significant impact on recovery from property damage. Reinforcing structural elements (roof, walls etc.) may strengthen the existing property so that it could better withstand strong winds and heavy rain; yet, unfortunately, it may not do much to prevent flood damage. The same is the case for building higher floors or mezzanines, as lower parts of the home remain vulnerable. Heavy or bulky assets such as vehicles, refrigerators, washing machines and furniture, which are costly to repair or replace when damaged by floods are difficult or impossible to move to higher floors and thus could not be spared from flood damage. This result certainly does not imply that reactive, anticipatory and preventive measures are necessarily better than proactive measures in all aspects. Higher floors can provide safe refuge from floods, thereby saving lives, improving welfare, possibly removing the need to evacuate elsewhere and allowing household members to stay with their property. However, in terms of preventing flood damage and speeding up recovery, proactive measures did not have a significant effect.

To summarise, the results show that household income, access to credit (borrowing), the use of a flood alarm system, access to safe shelter, membership in a community organisation, adoption of disaster-specific anticipatory measures and adoption of general preventive measures significantly reduced the time it took for affected households to recover from property damage. Conversely, property damage cost, being an informal settler (or squatter) and, contrary to expectations, having attended disaster-preparedness training significantly increased recovery time. Evacuation, relief aid, type of housing, education, household size and frequency of flooding in the area did not have significant effects.

\section{Conclusion}

Using data gathered through a survey of 400 households from four barangays in Marikina City that were most severely affected by the flood of August 2012, the study sought to analyse the factors influencing property damage recovery time of households to assess their adaptive capacity.

Households reported property damage equal to an average of PHP 33142 (USD 771), which was equal to $165.0 \%$ of their average monthly household income, or $13.8 \%$ of their average annual income. Television sets, rice cookers, refrigerators and washing machines were the most commonly damaged household appliances (more than $40.0 \%$ of households). Damage to vehicles and computers were most costly. Roofs $(33.0 \%)$ were the most commonly damaged parts of the house, followed by exterior and interior walls (28.0\%).

Interval regression was used to investigate the factors influencing property damage recovery, measured as the time it took for households to fully repair or replace damaged property. The results show that household income, access to credit (borrowing), the use of a flood alarm system, access to safe shelter and membership in a community organisation significantly reduced recovery time. The adoption of disaster-specific anticipatory measures and of general preventive measures also significantly reduced the time it took for affected households to recover. Conversely, property damage cost, being an informal settler or squatter, and, contrary to expectations, having attended disasterpreparedness training significantly increased recovery time.

As expected, access to economic resources enabled affected households to recover faster. The importance of borrowing in aiding recovery is confirmed by regression results and supported by survey findings that $37 \%$ of households had borrowed funds from banks, informal lenders, friends or relatives to finance repairs or replacements. In contrast, relief aid - specified as temporary shelter, food, water, clothing, medicine and monetary donations - did not have a significant impact on recovery. Although these forms of help provided temporary relief to affected households, they did not affect the time it took for households to recover from property damage. Governments and organisations interested in helping families recover from property damage may thus find alternative strategies, such as extending affordable credit to affected households, to be more helpful than simply focusing on relief operations.

Being alerted by the flood warning system significantly reduced recovery time of affected households, as it allowed members of the household to prepare for the flood by moving valuables to higher ground and evacuating to safe shelter, access to which was also found to have significantly reduced recovery time. The dissemination of clear and relevant information through reliable warning systems is thus highly recommended, along with the provision of safe shelter.

The adoption of anticipatory behaviour (monitoring weather updates, moving valuables to higher ground upon receiving warning etc.) and of general preventive measures (preparing evacuation plans, storing food and medicine, trimming branches before the monsoon season etc.) both significantly reduced recovery time. However, the adoption of proactive measures (e.g. building higher floors, reinforcing homes, buying property insurance) had no significant effect. This result does not necessarily mean that proactive measures should be discouraged. Theoretically, proactive behaviour can improve a household's chance of avoiding great costs when disaster strikes and can significantly enhance their ability to survive so much so that crises become much less 'disastrous'. However, such proactive measures can also be very costly. The study's findings suggest that anticipatory behaviour and general preventive measures, which are generally less expensive than proactive measures, may be enough to improve property damage recovery.

Findings of the study also support the effectiveness of flood warning systems. The current alarm system in Marikina City has proven to be of critical importance. It is recommended that this system be properly maintained and expanded to 
cover a wider area. Of course imperative to the effectiveness of this warning system is the proper education on siren warnings and their meanings.

Recommendations can also be made with regards to postdisaster management. Close to a third of respondents had to borrow through informal channels, either relying on social or family ties or having to pay high interest rates charged by loan sharks. Governments and charitable organisations interested in improving household property damage recovery are recommended to think beyond relief aid, which provides important but temporary support. Easing financial constraints such as by facilitating access to credit have a greater impact on long-term recovery. Government should thus continue expanding the reach and availability of low-interest rate calamity loans through social security (PagIBIG, SSS and GSIS).

\section{Acknowledgements Competing interests}

The author declares that he has no financial or personal relationships that may have inappropriately influenced him in writing this article.

\section{References}

Blaikie, P., Cannon, T., Davis, I. \& Wisner, B., 1994, At risk: Natural hazards, people's vulnerability and disaster, Routledge, London.

Brooks, N. \& Adger, W.N., 2005, 'Assessing and enhancing adaptive capacity', in B. Lim \& E. Spanger-Siegfried (eds.), Adaptation policy frameworks for climate change: Developing strategies, policies and measures, pp. 165-181, Cambridge University Press, Cambridge.

Brooks, N., Adger, W.N. \& Kelly, P.M., 2005, 'The determinants of vulnerability and adaptive capacity at the national level and the implications for adaptation Global Environmental Change 15, 151-163. http://dx.doi.org/10.1016/j. gloenvcha.2004.12.006
Dalziell, E.P. \& McManus, S.T., 2004, 'Resilience, vulnerability, and adaptive capacity: Implications for system performance', paper presented at the First International Forum for Engineering Decision Making, Soos, Switzerland, 06-08 December viewed 02 October 2013, from http://www.resorgs.org.nz/images/stories/pdfs/ resorgs_ifed_dec04_edsm.pdf

Jarungrattanapong, R. \& Manasboonphempool, A., 2011, 'Adaptive capacity of households and institutions in dealing with floods in Chiang Mai, Thailand', Economy and environment program for South-East Asia (EEPSEA) research Economy and environment program for South-East Asia (EEPSEA) research
report 2011-RR2, viewed 02 October 2013, from http://www.eepsea.net/ pub/rr/2011-RR2-Rawadee\%20Jarungrattanapong\%20and\%20Areeya\%20 pub/rr/2011-RR2-Rawade

O’Brien, K., Leichenko, R., Kelkar, U., Venema, H., Aandahl, G., Tompkins, H. et al., 2004, 'Mapping vulnerability to multiple stressors: Climate change and globalization in
India', Global Environmental Change 14, 303-313. http://dx.doi.org/10.1016/ India', Global Environmentc
j.gloenvcha.2004.01.001

Peñalba, L. \& Elazegui, D., 2011, 'Adaptive capacity of households, community organizations and institutions for extreme climate events in the Philippines', Economy and environment program for South-East Asia (EEPSEA) research report 2011-RR3, viewed 02 October 2013, from http://www.eepsea.net/pub/rr/2011 RR3-Linda\%20M\%20Penalba\%20and\%20Dulce\%20D\%20Elazegui.pdf

Rayner, S. \& Malone, E.L., 2001, 'Climate change, poverty, and intergenerational equity: The national level', International Journal of Global Environmental Issues 1 , 175-202. http://dx.doi.org/10.1504/IJGENVI.2001.000977

Schwarzer R. \& Schwarzer, C., 1996, 'A critical survey of coping instruments', in M. Ziedner \& N.S. Endler (eds.), Handbook of coping: Theory, research and applications, pp. 107-132, Wiley, New York.

Shen, Y., Zhu, Z., Li, L., Lv, Q., Wang, X. \& Wang, Y., 2011, 'Analysis of household vulnerability and adaptation behaviors to typhoon Saomai, Zhejiang Province, China', Economy and environment program for South-East Asia (EEPSEA) research report 2011-R4, viewed 02 October 2013, from http://www.eepsea.net/pub/ rr/2011-RR4-Yueqin\%20Shen,\%20Zhen\%20Zhu,\%20Lanying\%20Li,\%20Qiuyu\%20 Lv.pdf

Smit, B. \& Pilifosova, O., 2001, 'Adaptation to climate change in the context of sustainable development and equity', in J.J. McCarthy \& O.F. Canziani (eds.), Climate change 2001: Impacts, adaptation and vulnerability, n.p., Contribution of Working Group III to the 3rd Assessment Report of the Intergovernmental Pane on Climate Change.

Susandi, A., Pratiwi, D.W., Tamamadin, M., Fadila, M.M., Violiza, T., Suwarto, T. et al., 2011, 'Adaptive behavior assessment based on climate change event: Jakarta's flood in 2007', Economy and environment program for South-East Asia (EEPSEA) technical report, viewed 10 October 2013, from http://www.eepsea.net/pub/tr/ Armi-Susandi-etal-Technical-Report.pdf

Twigg, J., 2004, 'Disaster risk reduction: Mitigation and preparedness in development and emergency programming', Good Practice Review 9, Overseas Development Institute, London.

Van der Veen, A. \& Logtmeijer, C., 2005, 'Economic hotspots: Visualizing vulnerability to flooding', Natural Hazards 36, 65-80. http://dx.doi.org/10.1007/s11069$004-4542-y$ 